\title{
The Significance of Preplanning and Faculty Engagement in Curriculum Change
}

\author{
Shelley Cobbett ${ }^{1}$ and Mary van Soeren ${ }^{2}$ \\ ${ }^{1}$ Site Administrator, Yarmouth Campus, BScN Arctic Nursing Coordinator, Nunavut \\ Campus, Dalhousie University School of Nursing, Halifax and Yarmouth, Halifax, \\ NS, Canada \\ ${ }^{2}$ Director, Canadian Healthcare Innovations, Inc, Toronto, ON Associate Professor \\ (Standing Appointment), Arthur Labatt Family School of Nursing, Western \\ University, London, ON, Canada \\ ${ }^{1}$ Shelley.Cobbett@dal.ca, ${ }^{2}$ mvanso@uwo.ca
}

\begin{abstract}
The challenge of curriculum renewal in nursing is ensuring a balance of rigor with a flexible, robust evidence-informed curriculum. To achieve this, the faculty at Dalhousie University School of Nursing used a unique and creative approach to develop a new nursing curriculum. Extensive preplanning, utilization of small working groups, working through consensus building, and utilizing a project plan engaged faculty in all facets of the curriculum development. Draft plans were developed which were reviewed and revised by all faculty through multiple creative planning events. This process allowed consensus around key decisions such as the philosophical underpinning of the curriculum, core themes, and new educational approaches. Using this framework, coupled with preplanning and data collection before starting the curriculum revision process allowed faculty to have a Senate-approved new nursing curriculum in about 18 months from initial discussions and resulted in high levels of faculty engagement.
\end{abstract}

Keywords: Curriculum development framework, Faculty engagement, Preplanning, Renewal

\section{Introduction}

McCoy and Anema's framework was adapted to guide the curriculum process [1]. Calls for a radical transformation in nursing education to focus on people-centered care with the integration of social, economic, and technological forces have been suggested as essential to maintaining relevance in the $21^{\text {st }}$ century [2]. Here we report on one university's curriculum framework used to guide the development of a new nursing curriculum that responds to this call. Pre-planning guidelines and specific strategies developed to maintain momentum and creativity are presented to assist other schools of nursing as they ponder their response to transformation in nursing education.

Article history:

Received (March 31, 2019), Review Result (July 7, 2019), Accepted (November 22, 2019) 


\section{Background}

With the current knowledge explosion, it is simply not possible to teach students everything in micro detail that they are required to know [3]. The issue of how to be responsive to the current healthcare environment and proactive to engage students in the journey to become professional nurses is not our unique experience [4]. The process of curriculum revision in nursing has been noted as laborious and time-intensive, involving reviewing existing data, gaining faculty and stakeholder support, and navigating internal and external approvals [5]. In addition to these aspects of curriculum development, we had unique internal and external pressures to have our curriculum designed, approved, and implemented within two years. The purpose of this paper is to share our journey to help inform other nursing faculties who are contemplating curriculum revision and/or development.

\section{Our journey}

\subsection{The beginning}

In keeping with our maritime location and identity, we used an ocean voyage metaphor to frame the journey. We could not set sail until we had a sound navigational plan that would guide decisions while maintaining individuality as a school and capitalizing on the individual creativity and expertise of faculty. Thus, we began with a data collection phase to inform the approach and enable us to delineate our curriculum development framework complete with a project plan. Our data collection included several sources [Table 1].

Table 1. Summary of preplanning data collection

\begin{tabular}{|c|c|c|}
\hline Source of Data & $\begin{array}{l}\text { Method of Data } \\
\text { Collection }\end{array}$ & Salient Points \\
\hline $\begin{array}{l}\text { Students (Past and } \\
\text { Current) }\end{array}$ & $\begin{array}{l}\text { Program and Exit } \\
\text { Student Surveys } \\
\quad(2002-2012)\end{array}$ & $\begin{array}{l}\text { More focused clinical opportunities; desire for specialization } \\
\text { within a generalist curriculum; elimination of perceived } \\
\text { repetition with reinforcement of concepts throughout the } \\
\text { curriculum; more apparent linkages between theory and } \\
\text { practice; flexible course scheduling and delivery; smaller class } \\
\text { sizes; engagement with research-intensive faculty; greater } \\
\text { emphasis on research and leadership in practice; and, more } \\
\text { opportunities for clinical service learning. }\end{array}$ \\
\hline $\begin{array}{l}\text { Practising } \\
\text { Registered Nurses, } \\
\text { patients, and } \\
\text { caregivers }\end{array}$ & $\begin{array}{l}\text { Town Hall Meetings } \\
\text { and Focus Groups }\end{array}$ & $\begin{array}{l}\text { Strong theory to practice connections; communication; and, } \\
\text { time and organizational management skills. } \\
\text { Patients/caregivers wanted nurses to focus on what matters to } \\
\text { them the most and see them as a person and not a "disease or } \\
\text { condition". }\end{array}$ \\
\hline $\begin{array}{l}\text { International } \\
\text { Nursing Think Tank } \\
\text { on Future Directions } \\
\text { for Undergraduate } \\
\text { Nursing Education }\end{array}$ & $\begin{array}{l}\text { Invitational Think } \\
\text { Tank at the } \\
\text { University (2012) }\end{array}$ & $\begin{array}{l}\text { Development of formal, structured partnerships between } \\
\text { service and education to address quality and relevance of } \\
\text { clinical practica and transition to practice; creation of an } \\
\text { inventory of innovations in nursing pedagogy for local } \\
\text { application and testing; and, a need to create opportunities for } \\
\text { students to specialize in a selected area of practice while } \\
\text { retaining generalist preparation. }\end{array}$ \\
\hline $\begin{array}{l}\text { Curriculum Experts } \\
\text { Current Program } \\
\text { Review }\end{array}$ & $\begin{array}{l}\text { Two clinical experts } \\
\text { conducted an onsite } \\
\text { program review }\end{array}$ & $\begin{array}{l}\text { Undertake a deliberate curriculum revision that sets the vision, } \\
\text { philosophy, and framework for the } 21 \text { st century for the nurse } \\
\text { you want you graduate to become; align revision with the } \\
\text { future directions of health care and the role of } 21 \text { st-century } \\
\text { nursing; encourage the infusion of both the formal and } \\
\text { informal curriculum with opportunities for faculty/students to } \\
\text { discuss existing and emerging nursing science as it impacts }\end{array}$ \\
\hline
\end{tabular}




\begin{tabular}{|c|c|c|}
\hline & & $\begin{array}{l}\text { care; pay particular attention to the quality of student } \\
\text { engagement as opposed to time-intensive engagement [e.g., } \\
\text { quality and progression of clinical vs. hours of clinical]; make } \\
\text { room in the curriculum for creative engagement and activity } \\
\text { of faculty and students as the 'energy source' for innovation; } \\
\text { and, find ways for the tenure track faculty to more } \\
\text { meaningfully engage with undergraduates, especially as role } \\
\text { models for research and practice. }\end{array}$ \\
\hline $\begin{array}{c}\text { National } \\
\text { Environmental Scan }\end{array}$ & $\begin{array}{l}\text { Website review and } \\
\text { survey of Schools of } \\
\text { Nursing in Canada } \\
\qquad(\mathrm{n}=12)\end{array}$ & $\begin{array}{l}\text { Some schools of nursing have already developed and are } \\
\text { implementing an integrated BScN Curriculum, most in } \\
\text { partnership with the service sector; others offer an exclusively } \\
\text { six-semester, two-calendar year model; wide uptake of } \\
\text { simulation learning in almost all nursing programs especially } \\
\text { since the release of the landmark NCSBN Simulation Study } \\
\text { (REF) which found that up to 50\% of clinical practice within a } \\
\text { nursing program could be replaced with clinical simulation } \\
\text { learning with no differences in student learning outcomes nor } \\
\text { any noted differences in graduates at six months of } \\
\text { employment; and, over } 96 \% \text { of nursing programs in Canada } \\
\text { utilize innovation clinical placements (ICPs) and } 63 \% \text { of } \\
\text { schools indicated that their use of ICPs have increased over } \\
\text { the past five years (REF) noting that ICPs promote student } \\
\text { initiative, engagement, creativity in decision-making, critical } \\
\text { thinking and professional relationships with communities. }\end{array}$ \\
\hline $\begin{array}{l}\text { Consultation with } \\
\text { Two Canadian } \\
\text { Universities }\end{array}$ & $\begin{array}{c}\text { Face-to-face } \\
\text { meetings and onsite } \\
\text { visits }\end{array}$ & $\begin{array}{l}\text { Integration of classroom teaching with clinical practice; move } \\
\text { from decontextualized knowledge to teaching for a sense of } \\
\text { salience, from critical thinking to clinical reasoning and } \\
\text { multiple ways of knowing, and from socialization and role } \\
\text { taking to professional transformation; undergraduate nursing } \\
\text { education is to prepare a generalist with opportunities for } \\
\text { focused areas of practice. }\end{array}$ \\
\hline $\begin{array}{l}\text { Provincial } \\
\text { Registered Nurse } \\
\text { Education Review } \\
\quad \text { (government } \\
\quad \text { agencies, all } \\
\text { provincial university } \\
\text { SON, service sector, } \\
\text { RNs, stakeholders) }\end{array}$ & $\begin{array}{c}\text { Face-to-face } \\
\text { meetings, synthesis } \\
\text { review, the resulting } \\
\text { report }\end{array}$ & $\begin{array}{l}\text { Offer a rich mix of shared (common) services, resources and } \\
\text { talents to students at each school while also providing } \\
\text { specialized skills, programs and talents that are unique to each } \\
\text { school; provide a level playing field for students across the } \\
\text { province while meeting regional and local needs; improve the } \\
\text { student experience within and across schools of nursing and in } \\
\text { transition from student to professional; meet the needs of } \\
\text { employers in the service sector, including the knowledge and } \\
\text { skill of generalist baccalaureate graduates entering highly } \\
\text { specialized practice settings; scale up access to distance } \\
\text { education learning and a range of programs at each site; } \\
\text { reduce costs and duplication of effort and improve efficiency } \\
\text { and effectiveness through shared purchasing and deployment } \\
\text { of human and other resources; clinical partners' expression of } \\
\text { saturation of clinical learning placements; two graduation } \\
\text { dates rather than what occurs now when all nursing students } \\
\text { all graduate in May; shorter time frame from admission to } \\
\text { graduation; reduced attrition rates; more focused, concentrated } \\
\text { clinical placement rotations at specific points in the semesters } \\
\text { to ease student placement load and increase continuity of } \\
\text { student experience; offer specialty focus learning } \\
\text { opportunities; respond to global nursing faculty shortage } \\
\text { through better utilization of current faculty expertise; and, } \\
\text { achieve smoother transition to practice for graduates. }\end{array}$ \\
\hline $\begin{array}{l}\text { University's Centre } \\
\text { for Learning and } \\
\text { Teaching }\end{array}$ & $\begin{array}{l}\text { Face-to-face } \\
\text { meetings, } \\
\text { professional } \\
\text { development, and } \\
\text { feedback sessions }\end{array}$ & $\begin{array}{l}\text { Enhanced focus on the science of learning and teaching, } \\
\text { including strategies for assessment and evaluation and } \\
\text { invaluable feedback to assist us in planning for the } \\
\text { development of a new curriculum. }\end{array}$ \\
\hline
\end{tabular}




\begin{tabular}{|c|c|c|}
\hline $\begin{array}{c}\text { Provincial, National, } \\
\text { and International } \\
\text { initiatives }\end{array}$ & $\begin{array}{c}\text { Key documents were } \\
\text { reviewed }\end{array}$ & $\begin{array}{c}\text { Informed the planning and development of a new highly } \\
\text { integrated curriculum; greater emphasis on situational learning } \\
\text { and cognition translated as the acquisition of comprehension } \\
\text { through exposure to knowledge and concept application in the } \\
\text { relevant practice environment. }\end{array}$ \\
\hline
\end{tabular}

There were similarities between the internal data and what was reflected in seminal publications on changes needed in professional nursing education for the $21^{\text {st }}$ century [2][6]. Students and stakeholders echoed the call to action clearly articulated in the nursing literature. We also commissioned an external review of the undergraduate curriculum with two acknowledged leaders in nursing education - one from the United States and one from our region. The investment in this thorough review allowed us to begin with an evidenceinformed approach and later served us in supporting changes at the approvals level within the School and the broader university community.

Findings from this review were presented to the faculty. Following these discussions, decisions were confirmed regarding the curriculum leadership team from within the governance structure. The recently reviewed mission and vision for the School provided a basis for the planning. Questions related to "Where do we start?" and "How will we navigate this mammoth change?" came into focus after our School decided that a simple curriculum revision would not be sufficient to address the changes needed in the current context of nursing education. The curriculum development model and project plan were formed using the underlying premise that the process needed to be interactive, engaging, stimulating, transparent, creative, and spark excitement in faculty.

\subsection{Preplanning decisions}

\subsubsection{Consensus}

There are many ways to implement a consensus-building decision-making process. Consensus is defined as a general agreement; judgment arrived at by most of those concerned [7]. Our focus was on the process of reaching a consensus decision, by way of open, honest, transparent discussion and respectful debate. The theoretical aim for our consensus-making process included an inclusive and participatory egalitarian approach grounded in collaboration and cooperation [8].

It was acknowledged that group decisions are effective through consensus and all faculty members may not be in 100 percent agreement, but they can accept the decision of the group. This acknowledgment enabled the faculty to collectively move forward with implementing the change knowing the overall goal was offering a high-standard, current nursing curriculum. This consensus-making process allowed for better decisions and fostered greater group cohesion as well as set the stage for cooperative and successful implementation. The level of agreement necessary to finalize a decision is known as a decision rule [8][9]. At the onset of curriculum development faculty passed a decision rule for consensus and set as much agreement as possible (objectively, a minimum of $75 \%$ of agreement of faculty in attendance at the meeting). Ultimately voting was not required for any change because the agreement was reached through consensus.

\subsubsection{Meetings and working groups}

Consideration of how to move forward effectively was important, recognizing that there are different strategies regarding curriculum and faculty members have a variety of theoretical 
and practical approaches of equal importance. To utilize the content expertise of all faculty and maximize efficiencies, working groups were formed. These groups focused on distributed learning, technology in education, the philosophy of the program, communication, and curriculum.

There is much debate in the literature surrounding the ideal number of people for the effective functioning of working groups. There is a need to balance having sufficient, diverse input to allow for informed decision-making while limiting the size of the group to allow effective group dynamics and efficient use of human resources. Our experience demonstrated that a core group (5-6 people), including faculty and students, allowed for timely responses and adequate representation. Although there were "content experts" within the working group, the group identified its initial role as facilitating a strategic process and preparing draft curriculum documents for discussion and revision with faculty as a whole.

\subsection{Curriculum development framework}

The systems framework from McCoy and Anema [1] [Figure 1] was modified to guide our curriculum development for our context so that we could start near the end, i.e., "Who do we want our graduate to be?" The framework included the integration of the mission, vision, and values of the School and the faculty members' philosophies of nursing and teaching and learning into preparation for curriculum development. A project plan was created that engaged patients and their families, faculty, students, practicing Registered Nurses, service sector agencies, regulatory bodies, and, the University Centre for Learning and Teaching, in our curriculum development ([Table 2]: Template for Project Plan).

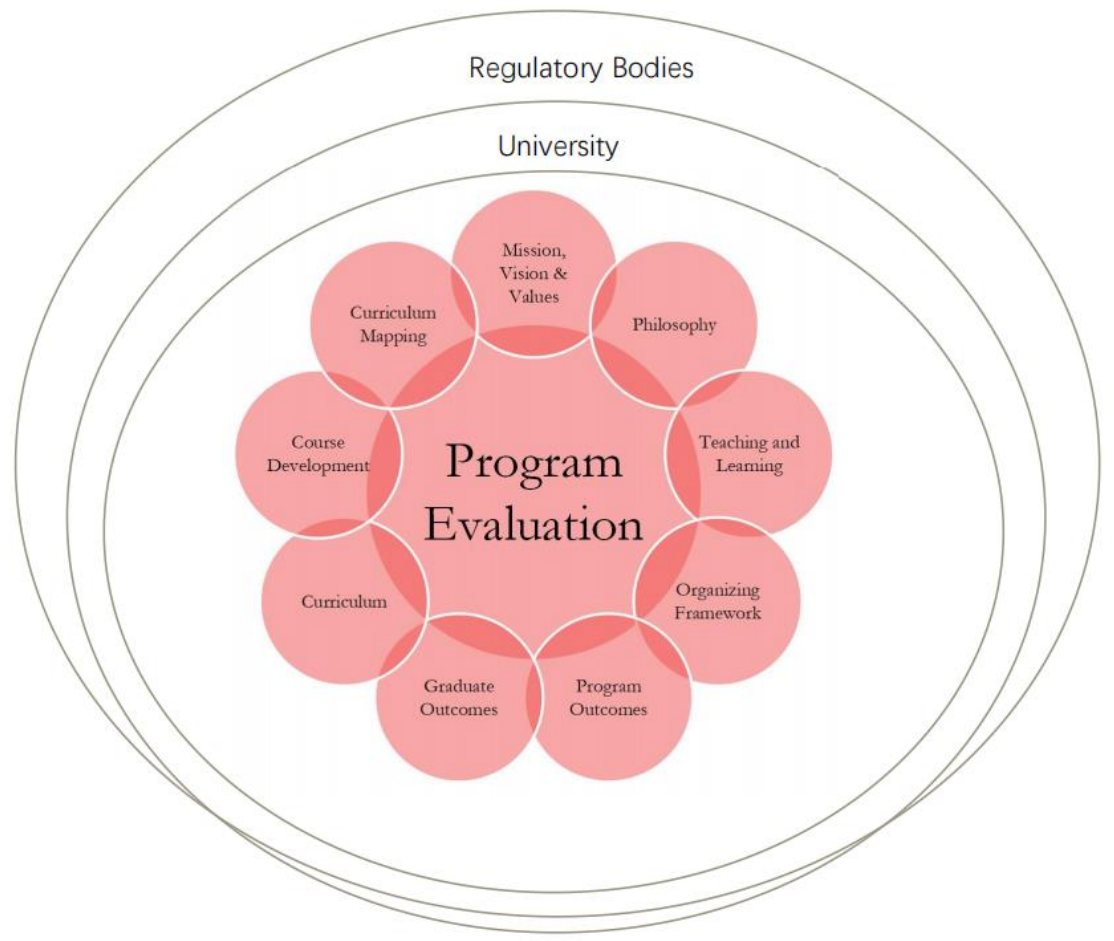

Figure 1. Curriculum development framework (Adapted from [1]) 
The preliminary work led to the adoption of a pedagogical educational framework to guide detailed curriculum development and the identification of core themes. This reflection against a backdrop of the School's strategic plan and research pillars created a new organizing framework for the undergraduate program. A review of the draft program and graduate outcomes was completed to maintain congruence with legislative changes for the practice of the Registered Nurse, Provincial Approval Regulations, National Accreditation Standards, and University Policies and Procedures. Once we were satisfied that regulatory requirements could be met within our vision and obtained confirmation from faculty that the outcomes addressed who we wanted our nursing graduate to be upon exiting our program, our task was to design a new curriculum to achieve the conceptualization.

Table 2. Project plan template with major task entry example

\begin{tabular}{|c|c|c|c|c|c|}
\hline \multicolumn{6}{|c|}{ Curriculum Development Project Plan } \\
\hline \multicolumn{6}{|c|}{$\begin{array}{l}\text { PURPOSE: The purpose of the Curriculum Development Group is to develop a new, highly integrated } \\
\text { curriculum and prepare for implementation in September } 2016 .\end{array}$} \\
\hline Major Task & Sub Tasks & Project Plan & Resources & Responsibility & Timeline \\
\hline $\begin{array}{c}\text { Required } \\
\text { curriculum } \\
\text { applications } \\
\text { and approvals }\end{array}$ & $\begin{array}{l}\text { List required } \\
\text { approval } \\
\text { bodies for the } \\
\text { new } \\
\text { curriculum }\end{array}$ & $\begin{array}{l}\text { Compile a list of } \\
\text { internal, } \\
\text { provincial, and } \\
\text { Atlantic approval } \\
\text { requirements }\end{array}$ & $\begin{array}{c}\text { Faculty of } \\
\text { Health } \\
\text { Professions } \\
\text { (FHP)- Dean's } \\
\text { Office } \\
\text { University } \\
\text { Senate } \\
\text { committee }\end{array}$ & Co-Chairs & $\begin{array}{c}\text { July } 20 \text {, } \\
2014\end{array}$ \\
\hline- & $\begin{array}{l}\text { Concept paper } \\
\text { approval } \\
\text { process }\end{array}$ & $\begin{array}{l}\text { Prepare concept } \\
\text { paper for } \\
\text { submission to } \\
\text { compiled list } \\
\text { from above }\end{array}$ & $\begin{array}{l}\text { FHP- Dean's } \\
\text { Office } \\
\text { University } \\
\text { Senate } \\
\text { committee } \\
\text { SON faculty } \\
\end{array}$ & $\begin{array}{l}\text { SON Director \& } \\
\text { Co-Chairs }\end{array}$ & $\begin{array}{l}\text { September } \\
18,2014\end{array}$ \\
\hline- & $\begin{array}{l}\text { Curriculum } \\
\text { approval } \\
\text { process }\end{array}$ & $\begin{array}{c}\text { Complete } \\
\text { application for } \\
\text { approval of new } \\
\text { BScN curriculum }\end{array}$ & $\begin{array}{l}\text { Obtain proposal } \\
\text { templates } \\
\text { specific to each } \\
\text { approval body }\end{array}$ & $\begin{array}{c}\text { Co-Chairs, } \\
\text { Development } \\
\text { Team }\end{array}$ & $\begin{array}{l}\text { March } \\
2015\end{array}$ \\
\hline- & $\begin{array}{l}\text { Academic } \\
\text { regulation } \\
\text { changes }\end{array}$ & $\begin{array}{l}\text { Revise applicable } \\
\text { regulations for } \\
\text { congruency with } \\
\text { the new } \\
\text { curriculum }\end{array}$ & $\begin{array}{l}\text { Review current } \\
\text { academic } \\
\text { regulations } \\
\text { (FHP and } \\
\text { Registrar's } \\
\text { Office) } \\
\end{array}$ & Co-Chairs & $\begin{array}{l}\text { November } \\
2015\end{array}$ \\
\hline- & $\begin{array}{l}\text { SON policy } \\
\text { changes }\end{array}$ & $\begin{array}{c}\text { Revise applicable } \\
\text { policies required } \\
\text { for the } \\
\text { implementation } \\
\text { of the new } \\
\text { curriculum }\end{array}$ & $\begin{array}{l}\text { Review current } \\
\text { SON policies to } \\
\text { assess for } \\
\text { applicability } \\
\text { within the new } \\
\text { curriculum } \\
\end{array}$ & $\begin{array}{c}\text { Undergraduate } \\
\text { Student Affairs } \\
\text { Committee }\end{array}$ & $\begin{array}{l}\text { March } \\
2016\end{array}$ \\
\hline
\end{tabular}

A supportive, spirited, intellectual environment that embraces respect for all was the guiding principle for working groups and curriculum development meetings. The environment created valued deference for the group through thinking, listening, and a spirit of inquiry, using this energy to explore the possibilities of what the $21^{\text {st }}$ century holds for nursing education; the debate focused on ideas, not specific areas of nursing or people, to further nurture curriculum cohesiveness. The timeliness of individual faculty participation is 
key to the development and implementation of a new curriculum- all hands needed to be on deck!

\subsection{We have a plan - time to launch our ship}

Once we had our curriculum development framework and project plan created, our navigational course was mapped, and it was time to leave the comfort and security of our home port! The Curriculum Planning Group took this task on with enormous energy and enthusiasm. Four faculty café style sessions were held. Each began with a short presentation outlining the logistics of the session and the anticipated outcome. It was more time effective for faculty to react and critique documents rather than create them so the planning group drafted templates in six key areas: current program changes (pilot projects which were designed as a proof of concepts for some proposed changes); envisioning graduate outcomes (i.e., answering: "Who do you want our graduate to be"); our philosophy of nursing; drivers for change; the proposed curriculum concept framework; and "what are your dreams and fears". These six areas became "ports of call".

Each port had a means for all faculty members to provide feedback and/or edit the draft documents. Approximately $85 \%$ of the faculty attended these sessions and all materials were circulated electronically to ensure everyone could participate. Suggestions from faculty were incorporated into the final curriculum concept paper. Next, a faculty meeting (95\% of faculty attended) and a summary of the feedback from the café sessions was presented with a plan for ongoing faculty participation and consultation as the curriculum concept paper came to life. Two additional open-space feedback sessions were requested by faculty members during this meeting, to provide an additional opportunity for discussion and critique of our evolving conceptual basis for the curriculum. Approximately $90 \%$ of the faculty was represented at these four-hour sessions. Feedback and input (verbal and written) were integrated into the next version of the curriculum framework.

The resulting feedback caused the Planning Group to consider how to frame the curriculum in terms of a single unifying theoretical model and/or a specific delivery strategy. The original version considered a concept-based curriculum and a single nursing theory as a basis for the curriculum, however, faculty asked that other options be considered for a variety of pedagogical reasons. In addition, faculty feedback revealed commonality across several themes such as our curriculum must be people-centered, equip students to provide culturally competent care and promote health, enact care that provides for diversity within populations, utilize knowledge of the social determinants of health, and focus care on vulnerable populations, including those approaching end of life. We achieved consensus on a crucial element of curriculum development, that is, rather than attempt to adapt existing nursing curricula models, we should map our course into new and uncharted territories. This realization was a fundamental turning point and caused a change in our course to contemplate the development of a highly integrated, vertically and horizontally fused curriculum that was people-centered; this was a new course, in a unique direction. The Planning Group was energized by this directional change and realized that traditional nursing curricula assumptions need not direct our development. We moved from asking ourselves "Why can't that be done?" to "Let's figure out a way to achieve what we want to accomplish". At this point we knew who we wanted our nursing graduate to be; now we were charged with the task of how we were going to get there.

It is often challenging to obtain consensus in a large faculty, especially regarding a singular theoretical underpinning for curricular development. After discussions of several approaches 
and points of view, the Curriculum Planning Group suggested that the main theoretical underpinning of our new curriculum be a pedagogical one based upon the science of learning and teaching that will direct our curriculum decisions, while our program foundation, or our beach, would be the 'critical analysis of diverse theories'. The acceptance of this direction in our journey marked another landmark turning point. Exposing students to diverse theories, rather than basing the entire nursing program on a sole theorist, will enable students to have a repertoire of frameworks to work within, shifting their frame of reference as required, leading to flexibility in situated cognition.

The pedagogical underpinning chosen to guide curriculum development became a merger of two theories for learning and teaching, Gardner's Five Minds for the Future [10] and Fink's Interactive Nature of Significant Learning Model [11]. Basing curriculum development on the science of learning and teaching directed us to value active learning and student engagement and assisted us with curriculum decision points related to the content, theory, classroom and clinical learning, assessment, evaluation, and inclusion. A detailed discussion of the pedagogical underpinnings of the developed curriculum is beyond the scope of this paper.

\section{Conclusion}

Key to the success of our curriculum planning was: the adoption of a curriculum framework; having a faculty-approved Curriculum Planning Group charged with incorporating ideas from other working groups into the new curriculum; and, having multiple opportunities and venues for faculty to discuss, debate and edit draft documents. The empowerment of the Planning Group allowed a small group of individuals to create draft documents for critique by faculty and opened discussion of the underlying framework and theory. The creation of a project plan was also instrumental in achieving transparency with the requirements for approvals based on specific timelines-it enabled us to chart our navigational course. While the timeline created a sense of urgency, it also made expectations clear and enabled everyone to be responsible to participate in the process.

The development of new nursing curricula is often seen as an overwhelming and insurmountable undertaking. In sharing our pre-planning experiences, we hope that we have sparked enthusiasm and have instilled the belief that curriculum development need not be onerous. Setting the stage for curriculum development to be creative, exciting, fun, and engaging, helps to mitigate the commitment, long hours, and hard work that is required to embark on such a journey. Using the analogy of curriculum development (in our case a voyage) and mapping our navigational course (our project plan) sparked interest and a genuine desire for faculty engagement. This interest lead to creativity becoming the norm and generated excitement for change - we thrived on the energy that this spawned and the resulting direction that it was not only acceptable but encouraged, us to look at things differently.

\section{References}

[1] J. McCoy and M. Anema, "Fast facts for curriculum development in nursing," New York, NY: Springer Pub Co., (2012)

[2] P. Benner, M. Sutphen, V. Leonard, and L. Day., "Educating nurses: A call for radical transformation," San Francisco, CA: Jossey-Bass, (2010) 
[3] S. Hendricks, C. Taylor, M. Wlaker, and J. Welch, J., "Triangulating competencies, concepts and professional development in curriculum revisions," Nurse Educator, vol.41, no.1, pp.33-36, (2016) DOI: 10.1097/NNE.0000000000000198

[4] M. Bouchard, B. Swan, A. Gerolamo, K. Black, K. Alexander, J. Bellot, J., and D. Dullivan, “Accelerating design and transforming baccalaureate nursing education to foster a culture of health," Journal of Nursing Education and Practice, vol.6, no.11, pp.97-103, (2016) DOI: 10.5430/jnep.v6n11p97

[5] G. Mitchell, C. Jonas-Simpson, and N. Cross, "Innovating nursing education: Interrelating narrative, conceptual learning, reflection, and complexity science," Journal of Nursing Education and Practice, vol.3, no.4, pp.30-39, (2013) DOI: 10.5430/jnep.v3n4p30

[6] J. Frenk, L. Chen, Z.A. Bhutta, J. Cohen, N. Crisp, T. Evans, T., and B. Kistnasamy, "Health professionals for a new century: Transforming education to strengthen health systems in an interdependent world," The Lancet, vol.376, no.9756, pp.1923-1958, (2010)

[7] Merriam-Webster, "Consensus definition," Merriam-Webster Dictionary, http://www.merriam-webster.com/dictionary/consensus

[8] T. Hartnett, "Consensus-oriented decision making," Gabriola Island, BC: New Society Publishers, (2011)

[9] S. Kaner, "Facilitator's guide to participatory decision-making," San Francisco, CA: Jossey-Bass, (2011)

[10] H. Gardner, "Five minds for the future," Boston, MA: Harvard Business Press, (2008)

[11] D. Fink, "Creating significant learning experiences," San Francisco, CA: Jossey Bass, (2013)

\section{Authors}

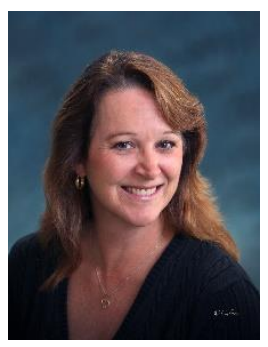

Dr. Shelley Cobbett, RN, GnT, MN, EdD

Assistant Professor

Site Administrator, Yarmouth Campus,

BSCN Arctic Nursing Coordinator

Dalhousie University School of Nursing, Halifax and Yarmouth

Halifax, NS

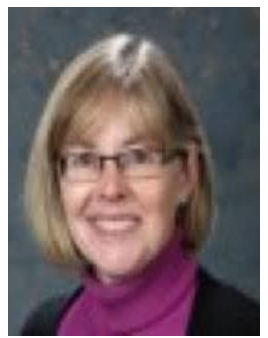

Dr. Mary van Soeren, RN, PhD

Director, Canadian Healthcare Innovations, Inc, Toronto, ON Associate Professor (Standing Appointment), Arthur Labatt Family School of Nursing, Western University, London, ON 
The Significance of Preplanning and Faculty Engagement in Curriculum Change

This page is empty by intention. 